\title{
The Islamic Banking Sector Of Pakistan: The Impact Of Leadership Opportunities, Gender Differences, Working Conditions And Employee Performance On Job Satisfaction Of Female Employees Of The Industry
}

\author{
Sobia Iqbal \\ Department of Public Administration \\ University of Karachi \\ Khalid Mehmood Iraqi \\ University of Karachi
}

\begin{abstract}
The findings of this research study is constructed depending the role of women in Islamic Banking industry of Pakistan. It has been conducted with an objective to determine the contrast of leadership opportunities, gender differences, working condition, employee performance with Job Satisfaction. The data has been collected from 200 male and female participants, representing the Islamic Banking Sector of Pakistan (Meezan Bank, Dubai Islamic Bank and Bank Islami). The result of the research shows a positive association in the selected dependent and independent variables. The study result further supports that in the current scenario the male gender participation for authoritative and leadership position is comparatively high as paralleled to female in the Pakistani Islamic Banking Sector of Pakistan. Further, it reveals that male working employees in the Islamic banking sector of Pakistan are far more satisfied as compared to female working participants. The result has reflected that the constructed model is significant (at the $\mathrm{p}<0.001$ level). The findings of this particular study possibly may assist the upper management to revisit their working environment policies and practices to consider females as equally responsible for challenging leadership roles, providing career path opportunities, and to promote Equal Employment Opportunities (EEO) in organizations.
\end{abstract}

Keywords: Leadership, Job Satisfaction, Career Path.

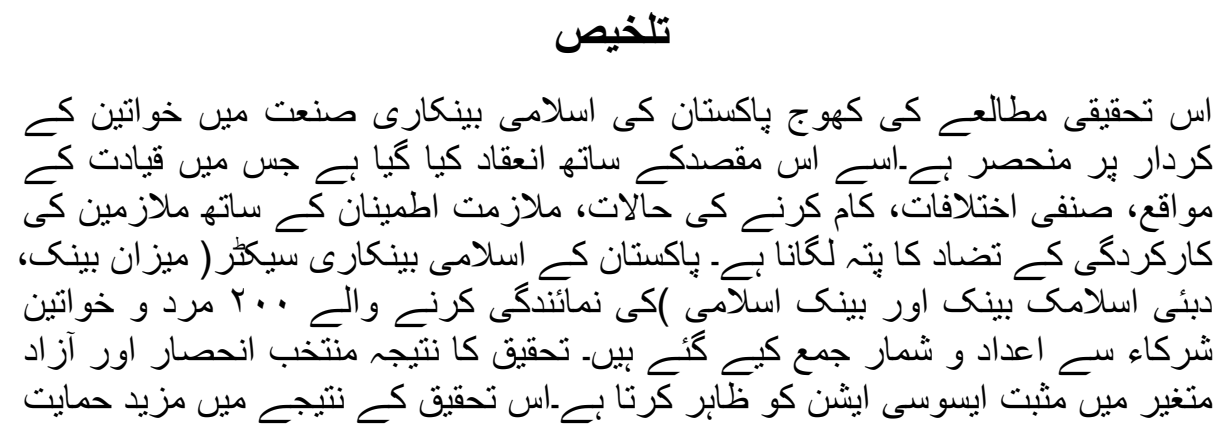




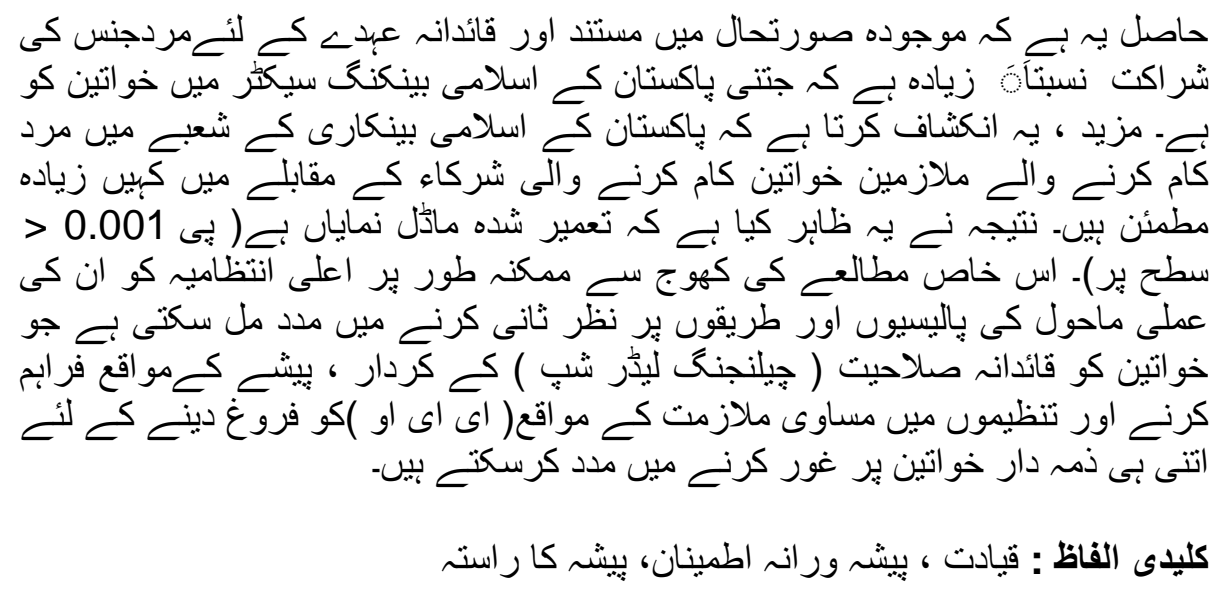

\section{Introduction}

Pakistani Islamic Banking sector is in bloom in current circumstances, the researchers are still exploring and have presented a strong bond in the Gender of leadership title and job satisfaction. This might be the influence or reflection of societal and cultural behavior followed by the country that male gender enjoys the superiority, the dominancy and is treated as the head of the family. Similarly, this norm is followed in the Pakistani Islamic Banking industry that most of the leadership roles are addressed by the male gender. The cultural values of the country addresses that the females are considered as less competent in terms of power and talent, therefore, they always remain dependent on the male gender, either the societal norms are not liberal enough to let and accept the female to speak stridently and confidently in the presence of a male.

In reference to the above-mentioned elements, a working woman encounters a number of challenges and hurdles to survive and compete with the male gender for a leadership position in Pakistani society. Sometimes in order to pursue their career, they have to make compromises for motherhood, and unhealthy marital life in one hand domestically, while they come across difficulty in maintaining work-life balance and facing gender discrimination and male dominancy working environment on the other hand professionally.

Despite being on merit, qualified and competent candidates, females face many problems to acquire and achieve an executive and managerial rank in the banking industry (Miller, J. L. 2006). The female employees have working hour restrictions and gets unproductive for mobility, they cannot easily deployed from one place to another (Aggarwal et al., 2000). In the banking industry, the female employees are merely considered to promote for decisive positions. They have comparatively less growing strategies and that is why 
they remain unsatisfied with their growth expectations and working environment (McCuddy et al., 2010).

Skilled and competent individuals prefer those organizations which have a better working environment and suitable working hours (Kelley, T, 2005). Studies reflect that satisfied employees stay in a longer span of service with the organization whereas unsatisfied employees switches and leave their jobs no matter how well they have been paid and what crucial position they are performing in an organization (Bhatti, K. \& Qureshi, T. 2007). One ideology of management states that unsatisfied employees switch for their leadership (bosses/ reporting individual). They change for their boss, not for the position or job.

Employees dislike their workplaces for long working hours, job fatigue, unsatisfactory income, weak work-life balance, and staff shortage, lack of motivation and communication, and hierarchical relationships of staff (Pavesic \& Brymer, 1990).

Okumus et al. (2010) highlighted the barriers and challenges of working women such as limited socialization time for family and friends, they have a compromise for their hobbies household duties and responsibilities.

This research paper explores and identifies the impact of basic demographic components and characteristics for employee satisfaction and the impression of gender for leadership opportunities simultaneously sightseeing different paradigms and dimensions of theoretical and managerial perspective to support and empower the organizational culture. Controlling other variables, the effort is made to reveal the impact of gender differences and leadership opportunities in the Pakistani Islamic Banking sector.

Paralleling to social and cultural norms and values of the country it has been supposing that the female gender is weak, indecisive, incompetent and cannot perform well in competition as compared to the male gender, therefore, females with cured with unfair professional practices in terms of promotions and leadership roles because of the male dominating society especially in the Pakistani Islamic Banking Sector. The conducted research will try to identify the difficulties that are faced by working women in the Pakistani Islamic banking industry.

This research study is reconnoitering the variable of the female gender on the job satisfaction and leadership opportunities in the Islamic Banking sector of Pakistan aiming to explore the following few mentioned research queries.

1. How the management does ensure to provide equal opportunities for leadership in male dominating society in the Pakistani Islamic banking sector? 
142 The Islamic Banking Sector of Pakistan: The Impact of Leadership Opportunities, Gender Differences, Working Conditions and Employee Performance on Job Satisfaction of Female

Employees of the Industry

2. What are the characteristics that contribute towards job satisfaction in female workforces of the Islamic banking sector in Pakistan?

3. What are the significant characteristics that lead to provide equal opportunities to female gender for leadership in the Pakistani Islamic banking sector?

4. What is the degree of job satisfaction in female working employees as compare to male working employees in the Islamic banking sector of Pakistan?

5. How the job policies supports to achieve job satisfaction in employees of the Islamic banking sector of Pakistan?

The practical association of this study may lead the banking industry and other financial units to enhance the working conditions and support the female employees to attain and acquire the positions of their dreams with dignity and job satisfaction without any gender discrimination and biases. The positively fair and equal acknowledgment for the efforts of the employees from the management may heighten the confidence of the male and female employees and enhance their motivation to perform better in competition with each other and impact significantly organizational performance in the discrimination-free working environment.

This particular study is intended to achieve and explore the influence of the job satisfaction on gender difference, leadership opportunities, working conditions and employee performance with respect to the female working employees in Pakistani Islamic banking sector aiming to:

1. To design a practical and theoretical framework from related reviewed literature for the Islamic Banking Sector of Pakistan.

2. To explore the female leadership opportunities without any gender biases in the Islamic Banking sector of Pakistan.

3. To investigate the influence of working conditions and job satisfaction in female employees of Islamic Banking Sector of Pakistan

4. To identify the impact of fair leadership position achievement on the motivation of female workforces in the Islamic Banking Sector of Pakistan.

\section{Review of Literature}

Due to classical or old-style perceptions, molds, traditions, and conventions for managerial position job responsibilities, it is very challenging for female gender to intervene and progress in higher-level leadership designations (Schaap et al., 2008). Likewise, developing countries, even the researches of a developed country like the US also reported low and uneven tendencies of opportunities for highly accomplished female's leadership achievements in recognized and well-esteemed reputed industries of America (Miller, J. L. 2006). 
In numerous social activities around the world, including tourism and hospitality, the management hitch and discourage female employment due to their domestic social lives and private intermediation and consider them less career-oriented as compared to male passionate individuals. Therefore they consider and offer less career-oriented privileges of growth that satisfy the competent female individuals (McCuddy et al., 2010).

Literature has also revealed the influence and commitment of motivated female employees on leadership positions and their connection with job satisfaction as well. However, this study is intended to explore, acknowledge and recognize the utility, the motivation and the commitment of female staff in the Islamic Banking industry of Pakistan, integrating with all the new emerging sectors for acknowledging female leadership and maximizing the productivity of the organization to provide equal opportunities for leadership and career growth.

The presented study is keen to ponder for selective demographic factors and drills-down to extract the parameters of job satisfaction especially in female employees who are rendering their services in Islamic banking sector of Pakistan with an ambition to reach the leadership career goals. It is intended to explore the scope of the hypothesis and search in the new dimensions to practice for overall management scenario.

The selective demographic variables may unwrap numerous sight full findings on gender differences and leadership opportunities, it may also comprehend the details along with ins and outs picture for gender differences in the Islamic banking sector of Pakistan.

Garcia-Bernal et al., (2005) study ensures that unlike other industries, in the service industry the forecasted labor force choice foresees and contingent on the perception of gender differences and the features of employee expectations from the assigned job to maximize the penetrating and thoughtful element of job satisfaction from the existing realities and practices of the management. Therefore it may conclude that the analysis of job satisfaction envisions the employee's interpretation and understanding of the nature of the business (Clark, 1996).

The data of some previously conducted researches show that there are some particular sets of characteristics that have been considered for the service industry to construct productive job and individual fit and it has complex the hiring and managing employees from gender differences perspective. This set of characteristics can be demanded remuneration, employment conditions, labor market, working hours, work-life balance, employee commitment, economic status, employee expectations, gender and individual qualification (Burke et al., 2008a). 
144 The Islamic Banking Sector of Pakistan: The Impact of Leadership Opportunities, Gender Differences, Working Conditions and Employee Performance on Job Satisfaction of Female

Employees of the Industry

The perception of the customers counts a lot, especially in the service industry. It gives a significant direction to the management to consider and instrument it, driving with a lead towards the policies, procedures, and practices to execute them for the employees to maximize the productivity of individuals for their workplace (Tuzun, 2009).

The Banking industry offers a wide variety of expertise in services, therefore it caters as an umbrella for extensive variability of jobs and diversity of manpower (Szivas et al., 2003). When we talk about organizational commitment and employee retention, job satisfaction act as a main contributor that predicts and interpret the relationship among the employee and the organization (Ryanet al., 2011).

Researches witnessed that satisfied employees are sturdily motivated and contribute positively to creating pleasant working circumstances and ambassador to take initiatives and explore new dimensions of success and development. Literature shows the evidence that a maximum level of job satisfaction is significantly associated with loyalty and commitment of the employee for longer-term and better employee performance (Rusbult et al., 1988).

(Hunter et al., 1997) has justified that customer orientation scores also give the glimpse of job satisfaction of employees and he has further supported his point by stating that the satisfied employee last pleasant experience for the customers and are competent enough in not only to satisfy and cater the customer demand but also engages the customer to construct a long term relationship with the business especially in the service industry. Literature says that unsatisfied employees are difficult to retain. The employees, no matter whatever their gender is, look forward to switch their jobs if they are not satisfied with their job (Ghiselli et al., 2001).

There is a term known as "Satisfaction Mirror", it reflects the contrast of association and relation in employee happiness and customer gratification in the service sector and creates a harmony on both ends where organization policies take the lead and drive them accordingly (Armstrong, M. 2000).

Job satisfaction is how the workforce is happy from their career and job, if employees find career growth in their jobs they get motivated. Equal opportunity for leadership may gear up the motivation of female employees to perform well and accomplish their career goals. Unfortunately, organizations do not take female contributions seriously. It create dissatisfaction in female employees (Pettijohn et al.2004).

Some scholars have specified the individualities to job satisfaction and divergent it in emotional and intellectual job satisfaction. Emotional job satisfaction is achieved when the employee is happy and appraises his overall working environment such as pay, 
working hours, benefits, leadership, organizational business, working environment and other numerous other job-related characteristics as per physiological, safety, love and belonging needs, whereas intellectual job satisfaction is achieved when one finds pleasant attitude for the future and prospects and growth opportunities for further personal development and it magnitude the employee job satisfaction towards self-esteem and self-actualization approach of Maslow hierarchy theory (Yang, 2010).

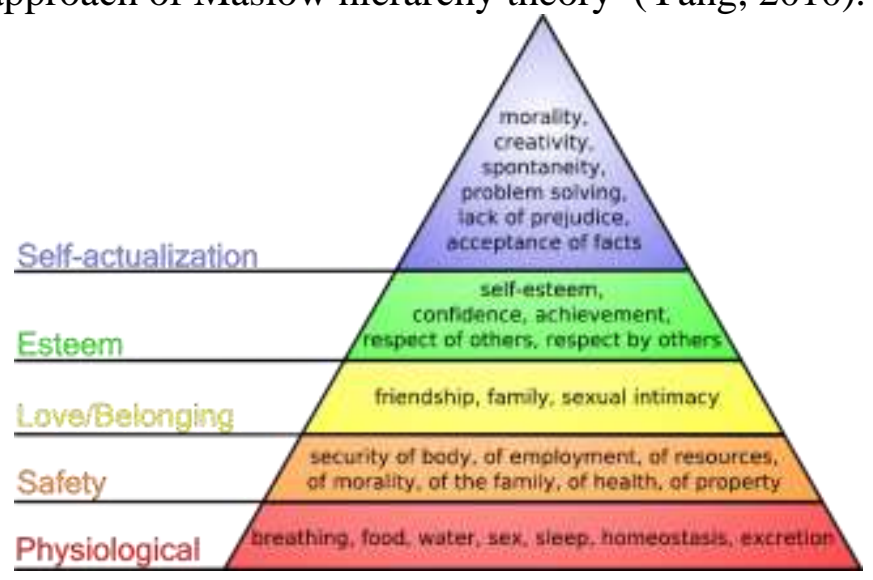

Scholars and researchers have emphasized to comprehend the motivating elements of job satisfaction for human resource management of the organization. Researches states that job satisfaction is a single-minded activity. It is not only subjected to the expectations and perceptions of the employee but it also assesses and evaluates the reality of their assigned professional jobs (Ferrer-i-Carbonell, 2009).

Locke (1969) explained job satisfaction as an emotional psychological condition that ensures, assesses and acknowledges the happiness and likeness of the employees for their job and related policies and practices of the management that facilitates their assigned official tasks. The main components of job satisfaction depend on the review of the working environment, working conditions, supervision and accountability, acknowledgment, work capacity and burden, growth opportunities, remuneration, job security and related financial and social outcomes and benefits.

Schneider \& Snyder (1975) declares job satisfaction as processed and strained psychological opinion went through the individual's thought process regarding the practices, philosophies and ideologies, strategies, procedures, policies, working environment conditions and prospects.

Aldrich, H. (1999) addresses and argue that job satisfaction also depends on demographic factors as well and it may vary person to person as per their cultural and social formation, gender, age, qualification, experiences, etc. He further connected job satisfaction with 
employee's expectations and actual practiced strategies and procedures of the management and argued that a low level of job satisfaction is extracted from unhappy, disappointed and unsatisfied employees of the organization.

Spector (1997) concluded the working environment, teamwork, nature of business, organizational practices and policies, communication, compensation, career growth, authority and accountability, fringe benefits, appraisal and acknowledgments, and job security as the main contributing elements for job satisfaction.

Literature has revealed for the studies that steered to analyze the bond for job satisfaction and sexual characteristics of the employees, however, some gaps have been observed for the Islamic Banking Sector of Pakistan with the noted agenda of female leadership. This research is mainly anxious to explore the findings of this conflicting and inconsistent agenda of literature in the Islamic banking sector of Pakistan for sexual role differences, female leadership, and job satisfaction.

The conclusions for the related topic in literature are inconsistent and vary for an organization to organization till today since 1950 (RashedAl-Ajmi, 2006). (Okpara et al., 2005; Clark, 1997; Aldrich, 1999) studies revealed that female employees are further satisfied as compared to male employees and they have experienced equal opportunities for leadership positions whereas (Mora and Ferrer-i-Carbonell, 2009) studies justify male employees satisfaction in comparison to female employees. (Linz, 2003; Koyuncu et al., 2004; Eskildsen et al., 2004; Rashid Al-Ajmi, 2006; Frye and Mount, 2007; Ward and Sloane, 2000) studies have not found any momentous differences in leadership opportunities and gender satisfaction as well.

Considering the meticulous demographic variables of Pakistan and Islamic Banking Sector, this study drills-down to explore the leadership opportunities for female employees and spot the construct of job satisfaction in employees of the bank.

\section{Theoretical Framework}

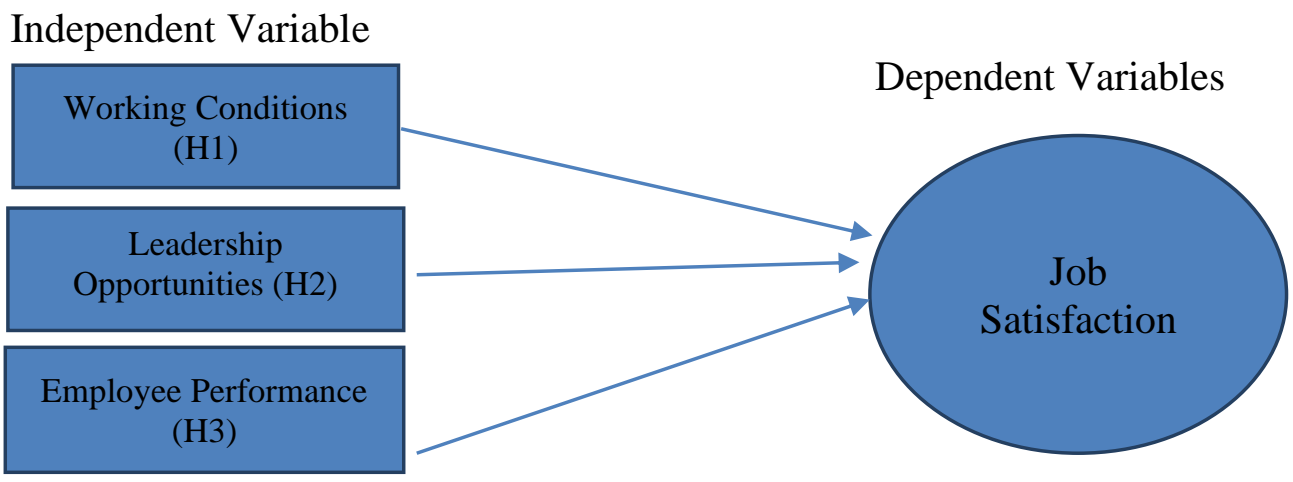


Considering Maslow Hierarchy theory and needs want and demand, the above theoretical framework has been drawn after in-depth literature study illustrating some relevant significance in independent and dependent variable and hypothesis of the study.

In the above framework the working conditions, leadership opportunities and employee performance has been considered as independent variable whereas job satisfaction of the employees are considered as dependent variable considering the gender dimension.

The hypothesis if the study states that:

- H1: There is a significant association in job satisfaction of female employees and working conditions of the Pakistani Islamic Banking Sector.

- H2: There is a significant association in Leadership opportunities and Job satisfaction of female staff in the Islamic banking sector of Pakistan.

- H3: There is a significant association in Employee performance and job satisfaction of female staff in the Pakistani Islamic banking sector.

\section{Research Methodology}

This study is conducted with an objective to explore the authoritative and leadership opportunities positions in controlled selected demographic variables considering the gender differences in Pakistani Islamic Banking industry and identifying their impact on Job Satisfaction in contrast to unlike variables predicted from the collected data of 200 male and female Islamic Banking Employees.

\section{Population \& Sample}

The data of this study has been collected from 200 employees of selected top 3 Islamic banks of Pakistan by convenient sampling method, serving at Karachi, Hyderabad, Islamabad, Lahore and Rawalpindi in Dubai Islami Bank, Meezan Bank and Bank Islami. These banks has been selected on the basis of their customer following. The researcher has distributed 270 questionnaires through social media, LinkedIn, Whatsapp, and Emails, out of which 219 have been received, 8 of them were incomplete and 11 of them where filled by the employees of other banks. Therefore 200 questionnaires have been considered for this research. 
148 The Islamic Banking Sector of Pakistan: The Impact of Leadership Opportunities, Gender Differences, Working Conditions and Employee Performance on Job Satisfaction of Female Employees of the Industry

\section{Questionnaire}

The questionnaire has been designed in 2 sections that is $\mathrm{A}$ and B. Section $\mathrm{A}$ is an attempted to collect demographic information of the participant that is name, age, marital status, sex/gender, education and qualification, gender of immediate boss, experience and designation. In order to analyze the job satisfaction of the workforce in the Pakistani Islamic banking sector. The second part of the questionnaire, section B has addressed the working conditions, job satisfaction, growth opportunities, and employee performance adopted by the study of (Weiss et al., 1967) after making some needed changes.

5 point Likert Scale has been used to collect the responses of the participants composed as

1- Strongly Disagree

2- Disagree

3- Neutral

4- Agree

5- Strongly Agree

21 questions lead to analyze job satisfaction of the employees in the Pakistani Islamic Banking Sector.

\section{Procedure}

The data have been tested through SPSS for descriptive analysis, reliability test has also been conducted along correlation.

\section{Results}

\section{Reliability Test}

Table: 1

Reliability test of questionnaire for the islamic banking sector of Pakistan

\begin{tabular}{|c|c|}
\hline Cronbach's Alpha & N of Items \\
\hline 0.867 & 29 \\
\hline
\end{tabular}

The above table is presenting reliability of the questionnaire by Cronbach's Alpha test of the variables. The result is 0.867 for 29 items for Islamic banking sector of Pakistan showing high reliability and supporting the results of the research. 


\section{Employee Participation}

Table: 2

Participants of the islamic banking sector $(\mathbf{n}=\mathbf{2 0 0})$

\begin{tabular}{|c|l|c|c|c|c|}
\hline \multicolumn{2}{|c|}{} & Frequency & Percent & Valid Percent & Cumulative Percent \\
\hline \multirow{3}{*}{ Valid } & Meezan & 79 & 39.5 & 39.5 & 39.5 \\
\cline { 2 - 6 } & Dubai Islami & 66 & 33 & 33 & 72.5 \\
\cline { 2 - 6 } & Bank Islami & 55 & 27.5 & 27.5 & 100 \\
\cline { 2 - 6 } & Total & 200 & 100 & 100 & \\
\hline
\end{tabular}

Employee Participation

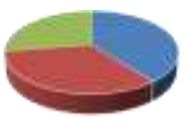

- Meezan Bank - Dubai Islami Bank - Bank Islami

The represented table is sharing the statistics of 200 participants. The participation from Meezan is 79, Dubai Islami Bank is 66 and 55 from Bank Islami.

\section{Gender Participation Analysis}

\section{Table: 3}

Gender of the participants

\begin{tabular}{|c|c|c|c|c|c|}
\hline \multicolumn{2}{|c|}{} & Frequency & Percent & Valid Percent & Cumulative Percent \\
\hline \multirow{3}{*}{ Valid } & Men & 122 & 61 & 61 & 61 \\
\cline { 2 - 6 } & Women & 78 & 39 & 39 & 100 \\
\cline { 2 - 6 } & Total & 200 & 100 & 100 & \\
\hline
\end{tabular}

Gender of the Participants

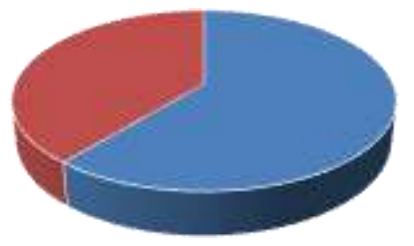

- Male - Female 
The above table is presenting the participation of male and female participants as $61 \%$ and $39 \%$ respectively.

\section{Marital Status}

Table: 4

Marital status of participants

\begin{tabular}{|c|c|c|c|c|c|}
\hline \multicolumn{2}{|c|}{} & Frequency & Percent & Valid Percent & Cumulative Percent \\
\hline \multirow{3}{*}{ Valid } & Married & 166 & 83 & 83 & 83 \\
\cline { 2 - 6 } & Unmarried & 34 & 17 & 17 & 100 \\
\cline { 2 - 6 } & Total & 200 & 100 & 100 & \\
\hline
\end{tabular}

The table represents that $83 \%$ of the participation of the respondents are married while $17 \%$ are unmarried.

\section{Qualification of the Participants}

Table: 5

Employee qualification

\begin{tabular}{|c|l|c|c|c|c|}
\hline \multicolumn{2}{|c|}{ Qualification } & Frequency & Percent & Valid Percent & Cumulative Percent \\
\hline \multirow{6}{*}{} & B.Com & 15 & 7.5 & 7.5 & 7.5 \\
\cline { 2 - 6 } & BA & 2 & 1 & 1 & 8.5 \\
\cline { 2 - 6 } & BE & 1 & 0.5 & 0.5 & 9 \\
\cline { 2 - 6 } & M.Com & 34 & 17 & 17 & 26 \\
\cline { 2 - 6 } & Masters & 9 & 4.5 & 4.5 & 30.5 \\
\cline { 2 - 6 } & MBA & 99 & 49.5 & 49.5 & 80 \\
\cline { 2 - 6 } & MS & 16 & 8 & 8 & 88 \\
\cline { 2 - 6 } & MSC & 5 & 2.5 & 2.5 & 90.5 \\
\cline { 2 - 6 } & Post Grad & 19 & 9.5 & 9.5 & 100 \\
\cline { 2 - 6 } & Total & 200 & 100 & 100 & \\
\hline
\end{tabular}

The above table of employee qualification represents the participation of $49.5 \% \mathrm{MBA}$, 9.5\% Post $17 \%$ M.Com and 9.5\% Post Graduates.

\section{Gender of Immediate Boss}

Table 6

Gender of Immediate Boss

\begin{tabular}{|c|c|c|c|c|c|}
\hline \multicolumn{2}{|c|}{} & Frequency & Percent & Valid Percent & Cumulative Percent \\
\hline \multirow{3}{*}{ Valid } & Male Leadership & 171 & 85.5 & 85.5 & 85.5 \\
\cline { 2 - 6 } & Female Leadership & 29 & 14.5 & 14.5 & 100 \\
\cline { 2 - 6 } & Total & 200 & 100 & 100 & \\
\hline
\end{tabular}


The above table represents the leadership of male and female gender in the Pakistani Islamic banking sector.

\section{Descriptive Statistics}

Table: 7

Mean and standard deviation

\begin{tabular}{|l|c|c|c|c|}
\hline & Minimum & Maximum & Mean & Standard Deviation \\
\hline Working Conditions & 2.60 & 5.00 & 4.1089 & .64732 \\
\hline Leadership Opportunities & 2.80 & 5.00 & 4.1244 & .52581 \\
\hline Employee Performance & 2.40 & 5.00 & 4.0467 & .53970 \\
\hline Job Satisfaction & 2.00 & 5.00 & 3.9667 & .72786 \\
\hline
\end{tabular}

The above table of descriptive analysis shows the mean and standard deviation of independent variables that is 4.1089 and 0.64732 for working conditions, 4.1244 and 0.52581 for leadership opportunities, 4.0467 and 0.53970 employee performance and for job satisfaction 3.9667 and 0.72786 .

\section{Descriptive Analysis}

Table: 8

Descriptive analysis

\begin{tabular}{|c|c|c|c|c|c|c|}
\hline Gender & & $\mathrm{N}$ & Minimum & Maximum & Mean & $\begin{array}{c}\text { Standard } \\
\text { Deviation }\end{array}$ \\
\hline \multirow[t]{5}{*}{ Female } & Working Condition & 78 & 2.40 & 5.00 & 3.8400 & .53018 \\
\hline & Leadership Opportunities & 78 & 2.80 & 5.00 & 3.9467 & .48692 \\
\hline & Employee Performance & 78 & 2.60 & 5.00 & 3.9156 & .68422 \\
\hline & Job Satisfaction & 78 & 2.00 & 5.00 & 3.7222 & .77464 \\
\hline & Valid N & 78 & & & & \\
\hline \multirow[t]{5}{*}{ Male } & Working Condition & 122 & 3.20 & 5.00 & 4.3022 & .50744 \\
\hline & Leadership Opportunities & 122 & 3.00 & 5.00 & 4.3022 & .55041 \\
\hline & Employee Performance & 122 & 2.75 & 5.00 & 4.2111 & .59102 \\
\hline & Job Satisfaction & 122 & 3.40 & 5.00 & 4.2533 & .46982 \\
\hline & Valid N & 122 & & & & \\
\hline Criteria & \multicolumn{6}{|c|}{$\begin{array}{l}\text { Female: } 3.25 \text { closely related to agree } \\
\text { Male: } 4.25 \text { closely related to strongly agree }\end{array}$} \\
\hline
\end{tabular}

The above table of descriptive analysis is presenting that:

- Females seems satisfied with satisfied with working conditions, leadership opportunities, employee performance and job satisfaction and falling above 
152 The Islamic Banking Sector of Pakistan: The Impact of Leadership Opportunities, Gender Differences, Working Conditions and Employee Performance on Job Satisfaction of Female

Employees of the Industry

the set criteria but they are comparatively less satisfied to the male gender participants.

- Male employees seems more comfortable and satisfied for the working conditions, leadership opportunities and job satisfaction and lies above from the mentioned criteria of 4.25 but they are slightly less satisfied with employee performance and staying at low point then the stated mentioned criteria.

\section{Correlation Analysis}

Table: 9

\section{Correlation}

\begin{tabular}{|c|l|c|c|c|c|}
\hline S. No & & $\mathbf{1}$ & $\mathbf{2}$ & $\mathbf{3}$ & $\mathbf{4}$ \\
\hline 1 & Job Satisfaction & 1 & $0.446^{* *}$ & $0.410^{* *}$ & $0.420^{* *}$ \\
\hline 2 & $\begin{array}{l}\text { Employee } \\
\text { Performance }\end{array}$ & & 1 & $0.355^{* *}$ & $0.349^{* *}$ \\
\hline 3 & $\begin{array}{l}\text { Leadership } \\
\text { Opportunities }\end{array}$ & & 1 & $0.505^{* *}$ \\
\hline 4 & Working Conditions & & 1 & 1 \\
\hline \multicolumn{5}{|c|}{ High correlation above 0.7} \\
Medium correlation between 0.5 and 0.7 \\
Low correlation between 0.3 and 0.5 \\
\hline
\end{tabular}

The above table of correlation represents that:

- The results of above table shows weak association in employee performance and job satisfaction as 0.446 .

- The results of the test shows weak association in leadership opportunities and job satisfaction and the value is 0.410 .

- There is weak association in working conditions and job satisfaction and the value is 0.420 .

\section{Discussion}

The results of this conducted study reveals that gender differences are directly associated with female employees job satisfaction in the Pakistani Islamic Banking sector. The participation of the employees is moderately high from Meezan Bank as compared to 
Bank Islami and Bank Dubai Islamic, and similarly the participation of male employees are more as compared to female staff serving in the Islamic Banking sector of Pakistan.

In order to explore the job satisfaction in employees serving in Islamic banking industry we have considered 3 main dependent variables that is working conditions, leadership opportunities and employee performance and it has been observed that in the current scenario the male leadership is greater as equated to the female leadership.

The results of the statistical data illustrated that the male working staff are comparatively more satisfied from the provided job leadership opportunities by their respective banks and employee performance but they are little uncomfortable for working conditions while female staff are less satisfied with the variables on the base of standard (3.25). Hence all the developed hypothesis are accepted.

The study has been conducted with some of the following mentioned limitations and opened new dimensions for further studies

1. The conducted research, has received only $39 \%$ participation from the female employees from only 3 main Islamic banks that is Meezan bank, Bank Islami and Dubai Islamic bank.The participation was mainly from Master Qualification predominantly with married marital status and has been only collected from Karachi, Hyderabad, Islamabad, and Rawalpindi. For this specific study, limited variables and controlled demographic factors has been considered.

2. This study is leaving a room for further studies. Some more related variables and demographic factors may change the results. The model of this study may apply to education industry, hotel management ventures, tourism and other service industry

\section{Conclusions}

This research has been conducted with an aim to explore and study the impact and influence of gender differences on job satisfaction in female employees for the Islamic banking sector of Pakistan.

The findings of this research study has analyzed strong association in gender difference and job satisfaction and due to male dominant societal approach, female employees participation reflected less satisfaction. The results also reflects that female are serving in very limited leadership positions in the Islamic banking sector. They encounter very limited leadership opportunities due to their social and domestic personal commitments. 
154 The Islamic Banking Sector of Pakistan: The Impact of Leadership Opportunities, Gender Differences, Working Conditions and Employee Performance on Job Satisfaction of Female

Employees of the Industry

The socio economic norm of the country is mainly depending on male gender. Females are considered as less competent candidates for decision making positions and executive designations by the management. The society consider female less eligible and less confident due to some religious norms as well and the Islamic banking industry of Pakistan is not acting differently from the societal, cultural and religious norms and practices. This approach and ideology can also disturb the emotional health of the female candidates as it may act as a hurdle for achieving their career goals.

At every step females have been challenged for inequality in workforce as well. In Pakistani society, women have very limited access to higher studies and therefore they are not considered for highly paid jobs and designations and at times they earns less pay then male gender for same nature of work and designation. Simultaneously female long term careers and career goals always remains questioned in Pakistani society.

\section{References}

Aggarwal, RL. \& Yousef, T. (2000) Islamic Banking and Investment Financing. Journal of Money, Credit and Banking, vol.32, pp.93-120.

Aldrich, H. (1999). Organizations Evolving. London: Sage Publications.

Armstrong, M. (2000). Strategic Human Resource Management: A Guide to Action. London, Kogan Page Publishers.

Bhatti, K. \& Qureshi, T. (2007). Impact of Employee Participation on Job Satisfaction, Employee Commitment and Employee Productivity. International Review of Business Research Papers, vol.3:2, pp.54-68.

Burke, R., Koyuncu, M. \& Fiksenbaum, L. (2008a). Work Experiences, Satisfactions and Psychological Well-Being of Female and Male Managers in the Hospitality Sector in Turkey. Equal Opportunities International, vol.27:6, pp.505-18.

Burke, R., Matthiesen, S., Einarsen, S., Fiskenbaum, L. \& Soiland, V. (2008b). Gender Differences in Work Experiences and Satisfactions of Norwegian Oil Rig Workers. Gender in Management: An International Journal, vol.23:2, pp.137-47.

Choudhury, M.A. \& Hussain, M. (2005) A Paradigm of Islamic Money and Banking. International Journal of Social Economics, vol.32:3, pp.203-217. 
Clark, A. (1996). Job Satisfaction in Britain. British Journal of Industrial Relations, vol.34:2, pp.189-217.

Employment Trends Report (2011). Pakistan Bureau of Statistics.

Eskildsen, J., Kristensen, K. \& Westlund, A. (2004). Work Motivation and Job Satisfaction in the Nordic Countries. Employee Relations. vol.26:1/2, pp.122-36.

Frye, W. \& Mount, D. (2007). An Examination of Job Satisfaction of General Managers Based on Hotel Size and Service Type. Journal of Human Resources in Hospitality \& Tourism, vol.6:2, pp.109-34.

Garcia-Bernal, Javier, Garallo-Castel, Ana, Marzo-Navarro, Mercedes, Rivera-Torres, Pilar. (2005). Job Satisfaction: Empirical Evidence of Gender Differences. Women in Management Review, vol.20:4, pp.279-288(10).

Ghiselli, R., La Lopa, J. \& Bai, B. (2001). Job Satisfaction, Life Satisfaction and Turnover Intent among Service Managers. Cornell Hotel and Restaurant Administration Quarterly, vol.42:2, pp.28-37.

Hunter, W. \& Tietyen, D. (1997). Business to Business Marketing: Creating a Community of Customers. Lincolnwood-Illinois, McGraw-Hill Professional.

Islamic Banking Bulletin. (2010). Islamic Banking Department of State Bank of Pakistan, June 2013. Islamic Banking Bulletin. Islamic Banking Department (SBP).

Jung, K., Jae Moon, M. \& Hahm, S.D. (2007). Do Age, Gender and Sector Affect Job Satisfaction? Results from the Korean Labor and Income Panel Data. Review of Public Personnel Administration, vol.27:2, p.125.

Kelley, T. (2005). Employee Satisfaction Results in Improved Profitability, Retrieved on April $4^{\text {th }}, 2008$ available http://www.indiangaming.com/istore/Nov05_Kelley.pdf. 667-81.

Li, L. \& Leung, R. (2001). Female Managers in Asian Service Industry: Profile and Career Challenges. International Journal of Contemporary Management, vol.13, pp.189-96. 
156 The Islamic Banking Sector of Pakistan: The Impact of Leadership Opportunities, Gender Differences, Working Conditions and Employee Performance on Job Satisfaction of Female Employees of the Industry

Linz, S. (2003). Job Satisfaction among Russian Workers. International Journal of Manpower, vol.24:6, pp.626-52.

Locke, E. (1969). What is Job Satisfaction?. Organizational Behavior and Human Performance, vol.4, pp.309-36.

McCuddy, M., Pinar, M. \& Birkan, I. (2010). Gender Bias in Managing Human Resources in the Turkish Banking Industry: Is Bias Impacted by Demographic Context? Proceedings of ASBBS, vol.17:1, pp.479-93.

Mehmood, A. (2002). Islamisation of Economy in Pakistan: Past, Present and Future. Islamic Studies, vol.41:4, pp.675-704.

Miller, J. L. (2006). Coach Yourself to Succeed @ Work: How to Achieve Optimal Performance and Job Satisfaction. CA, Dorrance Publishing Co.

Mora, T. \& Ferrer-i-Carbonell, A. (2009). The Job Satisfaction Gender Gap among Young Recent University Graduates: Evidence from Catalonia. Journal of Socio Economics, vol.38, pp.581-9.

Noe, F., Uysal, M. \& Magnini, V. (2010). Customer Satisfaction: An Encounter Approach. Routledge. London.

Okpara, J., Sqillace, M. \& Erondu, E. (2005). Gender Differences and Job Satisfaction: A Study of University Teachers in the United States. Women in Management Review, vol.20:3/4, pp.177-90.

Okumus, F., Sariisik, M. \& Naipaul, S. (2010). Understanding Why Women Work in Five-Star Hotels in a Developing Country and their Work-Related Problems. International Journal of Hospitality \& Tourism Administration, vol.11:1, pp.76-105.

Pavesic, D. \& Brymer, R. (1990). Job Satisfaction: What's Happening to the Young Managers? The International Journal of Administration and Management, Quarterly, vol.30:4, pp.90-6.

Pettijohn, C., Pettijohn, L. \& Taylor, A. (2004). The Relationships between Food Service Wait Staff Skills, Satisfaction, Commitment and their Levels of Customer 
Orientation. International Journal of Hospitality \& Tourism Administration, vol.5:2, pp.43-59.

RasedAl-Ajmi. (2006). The Effect of Gender on Job Satisfaction and Organizational Commitment in Kuwait. International Journal of Management; Poole, vol.23:4, pp.838-844, 943.

Rusbult, C., Farrell, D., Rogers, G. \& Mainous, A. III (1988). Impact of Exchange Variables on Exit, Voice, Loyalty and Neglect: An Integrative Model of Responses to Declining Job Satisfaction. Academy of Management Journal, vol.31:3, pp.599-627.

Ryan, C., Ghazali, H. \& Mohsin, A. (2011). Determinants of Intention to Leave a NonManagerial Job in Banking Industry of West Malaysia, International Journal of Contemporary Management, vol.23:3, pp.344-60.

Schaap, J., Stedham, Y. \& Yamamura, J. (2008). Casino Management: Exploring Gender-Based Differences in Perceptions of Managerial Work. International Journal of Management, vol.27, pp.87-97.

Schneider, B. \& Snyder, R. (1975). Some Relationships between Job Satisfaction and Organization Climate. Journal of Applied Psychology, vol.60:3, pp.318-28.

Spector, P.E. (1997). Job Satisfaction: Application, Assessment, Causes and Consequences. Sage Publications. London.

Szivas, E., Riley, M. \& Airey, D. (2003). Labor Mobility into Banking: Attraction and Satisfaction. Annals of Banking Management Research, vol.30:1, pp.64-76.

Tuzun, I. (2009). The Impact of Identification and Commitment on Job Satisfaction: The Case of a Turkish Service Provider. Management Research News, vol.32:8, pp.728-38.

Ward, M. \& Sloane, P. (2000). Non-Pecuniary Advantages Versus Pecuniary Disadvantages; Job Satisfaction among Male and Female Academics in Scottish Universities. Scottish Journal of Political Economy, vol.47:3, pp.273-303. 
158 The Islamic Banking Sector of Pakistan: The Impact of Leadership Opportunities, Gender Differences, Working Conditions and Employee Performance on Job Satisfaction of Female

Employees of the Industry

Weiss, D. J., Dawis, R. V. \& England, G. W. (1967). Manual for the Minnesota Satisfaction Questionnaire. Minnesota Studies in Vocation Rehabilitation, 22, 120.

Ernst \& Young (2013). World Islamic Banking Competitiveness Report (2012-2013). https://www.slideshare.net/EzzedineGHLAMALLAH/world-islamic-bankingcompetitiveness-report-2012-13

Yang, J. (2010). Antecedents and Consequences of Job Satisfaction in the Banking Industry. International Journal of Management, vol.29, pp.609-19.

Sobia Iqbal is Ph.D. Scholar in the Department of Public Administration, University of Karachi, Karachi, Pakistan.

Prof. Dr. Khalid Mahmood Iraqi is Vice Chancellor, University of Karachi. 